\title{
横浜市域における谷戸地形の特質と推移に関する一考察
}

\section{A Study on Topographic Characters and Transition of "yato" in Yokohama}

\author{
森 清和 ${ }^{*}$ 島村 雅英* \\ Seiwa MORI Masahide SHIMAMURA
}

\begin{abstract}
摘要 : 自然共生都市の重要な生態的拠点となる谷戸に関する基礎研究として、横浜市域における谷戸
生態系の成立過程, 谷戸地形の分布と特徵及びその現況について検討した。

横浜市域の谷戸地形は，縄文海進期に概成される。谷戸の農業開発による二次自然としての谷戸生 態系の成立は中世以降である。○谷戸と呼ばれる小字地名も数多く残されている。1 次谷戸数は 3751 か所で全市に分布する。横浜は「谷戸の発達した都市」といってもよい。

近年住宅開発等によって谷戸地形そのものや土地利用に大きな变化が見られる。現在の 1 次谷戸は， 2467 ヶ所である。そのうち, 自然的土地利用の多い谷戸は $944 ヶ$ 所となっている。
\end{abstract}

\section{1. 研究の背景と目的}

谷戸は，丘陵台地に平地が馬蹄形に入り込んだ地形である。谷 底面には谷戸田・小川・溜池等の水辺，三方を囲む斜面には雑木 林・畑等が展開する。谷戸の生態系は小さいが生物多様性の高い 複合生態系であり，ホタル，トンボ，カエルなどいわゆるふるさ と生物 "の生息地之なっている。横浜の典型的な田園景観であり, 市内河川の源流域としての水文的意義もある。その谷戸が土地改 変等により, 生態的な質の筫弱化などの危機に直面している。

自然共生都市の形成が大きな社会的課題になりつつあるが，そ の展開においては，ふるさと生物と共生可能な都市の生態的な質 も基本的な要件になる。その際, 横浜市においては, 谷戸は生態 系の面からきわめて重要な計画概念になると考えられる。

その問題意識に基づいて本研究では, 横浜市域の谷戸の形成過 程について基礎的な検討を行うこと，過去と現在の谷戸図の作成 等を通じて, 谷戸分布と推移, 地形的特徽, 土地利用等を把握す ること，以上の結果に基づき横浜市の環境形成等における谷戸の 重要性を明らかにすることを目的とした。

\section{2. 研究の方法}

\section{(1) 調查対象地}

行政計画への反映を考慮して，行政界の横浜市域を対象とした。 横浜市域は地形的には関東平野南部に位置し, 2 丘陵 (多摩, 三 浦), 2 台地 (下末吉, 相模原) 及び沖積低地で構成される。市 域面積は約 433kn², 最高点は三浦丘陵・大丸山（金沢区）の約 157 mである。

\section{(2) 研究方法}

第 1 に, 横浜の谷戸生態系の特質を把握するために, その形成 過程についての歴史的検討を行った。形成要因には大きく $2 つ の$ 側面がある。1 は谷戸地形の自然史的な形成であり, 2 は谷戸田 を骨格とする田園的土地利用による谷戸生態系の形成である。今 日の谷戸の生物環境は後者に由来する。なお本稿で谷戸生態系之 いう場合には，生態系における地形の重要性を意識したもので， 河川生態系, 池沼生態系といった用法に準じたものである。また 厳密な意味では，水田稲作を基礎とした田園的土地利用が成立す る以前にむそれなりの生態系はあったのであるが，ここでは今日 の生態系の特質を把握するという目的に鑑み, 田園的土地利用に 基づく谷戸の生態系を谷戸生態系ということにする。
第 2 に，横浜における谷戸の存在の重要性を明らかにするには 基礎情報として, 谷戸数と地形的特徵の把握が必要である。既存 の丘陵・台地, 軟弱地盤等の地形地質の調査研究成果を参考に, 谷戸図等を作成することにより, 流域別の 1 次の谷戸数並びに特 徵を検討した。

第 3 に, 現況の谷戸図を作成し谷戸の推移を比較するとともに, 谷戸の土地利用を調査し，現況を概観した。

\section{3. 研究の結果と考察}

\section{(1) 谷戸生態系の形成}

地形・地質についての調查研究をみるに ${ }^{2)}$ ，横浜市域の谷戸は 丘陵台地の雨水・湧水等の侵食による開析谷である。

最終的に横浜の谷戸地形の基底が形成されたのは, 最終水期に 現在よりも海水準が $100 \mathrm{~m}$ 以上低下していた海退期（ピークは約 2 万年前）である。その後, 縄文海進（ピークは約 6000 年前, 海水準は現在より約 $4 \mathrm{~m}$ 上昇）とともに, 流下速度が減じて今日 の沖積低地が形成される。また谷部では, 侵食土や崩落土等によ る埋没が起こり平坦面が形成される。これが埋没谷としての谷戸 地形の原形となる ${ }^{3)}$ 。谷戸地形の原形の時代は, 谷底面はアシ原, 斜面は常緑樹林が中心をなしていたと推定される。その後の人為 的な谷底面の谷戸田化と, 斜面林の肥料や薪炭利用による二次林 化等によって, 二次自然としての谷戸生態系が形成されたもの之 考える。その成立の時代並びに横浜において谷戸が発達している ことを地名及び水田開発史の研究成果に基づいて検討する。

谷戸地名研究の成果を概観すると，ヤト，ヤツ，ヤはほぼ同義 語である。山田は, 静岡以東, 主に関東に分布する東言葉で, 「古い時代に，主として稲作をしていた処の小地名である。だか ら山中には無いし, 広い平坦地にも殆どない。その平坦地から山

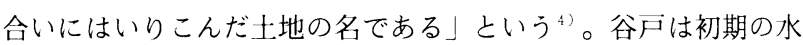
田開発に関係した地名である。神奈川県, ことに横浜市域はヤト 地名が多く, 千葉県ではヤッが多くなる。横浜市の谷戸地名は,

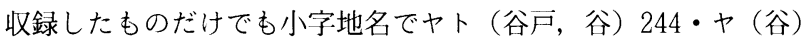
63, 合計 307 か所となっている ${ }^{5)}$ 。小字地名は集落名であり, 樹 枝状のま之まりを単位としたものが多い。さらに樹枝状の 1 次谷 戸（後述）にもほ上んど谷戸名がつけられている。山田は，「横 浜は正にヤト地帯」とも述べている ${ }^{6)} 。$

谷戸は，湧水はあり洪水被害はなく，アシ原を切り開き排水路

*横浜市環境科学研究所エコシティ研究室 
を造ればよく, 高度の技術力も不要であり, 開 田の適地であった。横浜地域の水田開発は, 谷 戸田から始まったと思われる。始まりの時代は 確認されていないが，古墳時代から奈良平安時 代に少しずつすすんだものと思われる。12 世 紀末の「吾妻鏡」には, 源頼朝の上洛時に鶴見 川流域の大規模な谷戸である寺家（じげ）周辺 の武士が随行していたことが記されている。当 時の東国武士の頼朝軍への参加は, 「開墾した 土地に対する権利の確保」齐 と言われており, 13 世紀前後には主要な谷戸の開発はある程度 すすんでいたものと思われる。

しかし, 高島は, 鶴見寺尾地域等の絵図資料 （1334 年）を解読し「水利条件に規定される谷 田=天水田が，全面的に開田されていなかった こと」 $\lrcorner^{8\rangle}$ を指摘している。水田史に詳しい山崎 や田淵は, 畿内に比へ関東の農地開発は遅れて おり, 関東の開墾が盛んになったのは鎌倉幕府 の成立以降之述べる。その開墾む当時は技術的 制約等により谷戸, 丘陵台地之中小河川の間等 が中心で, 中小河川の沖積地の新田開発は戦国 大名の登場以降, 大河川中流の氾らん原, 大河 川下流の三角州, 河口干潟の開発は近世と指摘 している ${ }^{9)}$ 。なお鶴見川汇濫源の低地は, 洪水 之用水不足 (河床勾配が緩やかで取水堰が設置 困難）で近代に至るまで未開田のところ（新横 浜周辺）屯あったように, 開田は遅れた。なお 谷戸田の開発は，水利条件等から谷の出口から 始まり奥に進んだと言われている ${ }^{10)}$ 。

新田開発がすすむと, アシ原の谷底面の人為 的な谷戸田化はもとより, 谷戸をとりまく樹林 帯への刚敷き, 薪炭, 茅場の需要屯高まり，そ れまでの常緑樹林帯に人手が入り, いわゆる雑 木林といわれる二次林が形成される。先の寺家 の地方文書は, 18 世紀初頭に隣村（鴨志田村） との入会地をめぐる争論のあったことを触れて いる。丘陵台地の卓越する横浜において入会地 をめぐる争論のあったことは, 谷戸を含む低地 の水田化が相当にすすんでいたことを示唆している。以上のこと 加ら，横浜における谷戸地形の本格的な二次自然化すなわち生物 相の豊かな谷戸生態系としての形成は, 中世以降で成立は近世に 行われたものと推定される。

なお天水に依存する谷戸田は，水不足を補うために湿田状態を 維持しなければならず，生産性は高くなかった。当時の生物相の 記録はないが, アカトンボ類, ホタル類，カエル類はまさにそ のような環境を生息地とする生物である"1。

\section{（2）谷戸数と谷戸地形の特徵}

本研究では, 谷戸地形を「丘陵台地に平地が馬蹄形に入り込み 三方を斜面に井まれた埋没谷」と規定し，横浜市の軟弱地盤（沖 積地）を解析した「横浜市地域環境特性図」122 を基礎に，地形図 (明治前期測量 2 万分 1 フランス式彩色地図, 日本地図センター) 等で補足し「横浜市谷戸図 $(1 / 25000) 」($ 図 1 ) を作成した。 (i) 谷戸数

水系図の谷次数（ストレーラ法）に則して，1 次谷戸を計測し た。1 次谷戸とは, 支谷戸を形成していない谷戸である。開析が 未発達で平地を形成していない谷及び谷壁斜面が 2 方向で谷戸景 観を形成していない平地は，谷戸概念に含めていない。計測は， 2 万 5 千分の 1 スケールの谷戸図で行った（図 2 ）。1 万分の 1

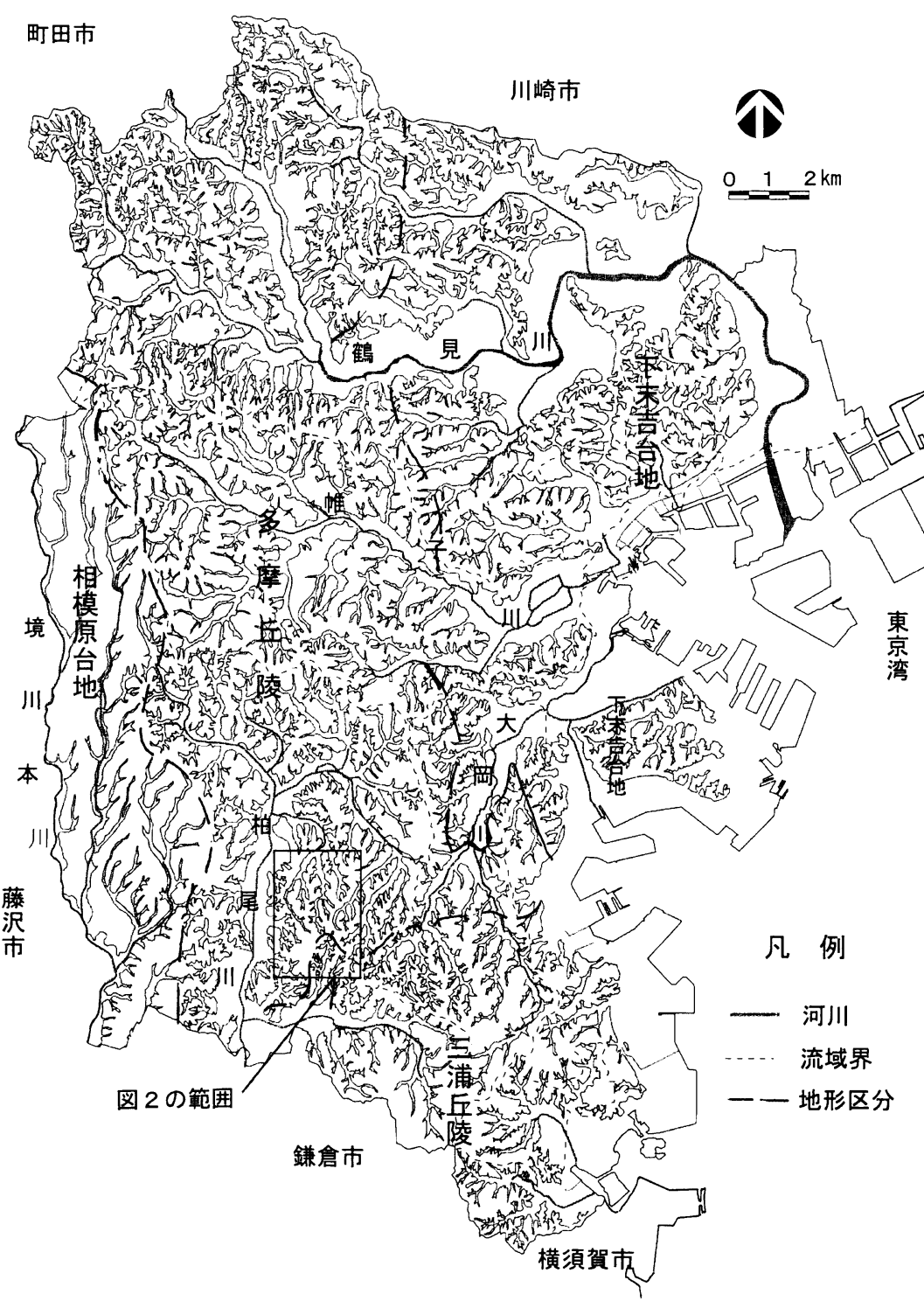

図- 1 横浜市谷戸図

以上の土地改変前の地 困が作成されていない こともあるが, 図 3 に 見られるように 2 千 5 百分の 1 スケールの地 形図（横浜市都市計画 局）と比較しても大き な違いは見られない。 若干の䛊差はあるかも しれないが, 全体像は 十分に 2 万 5 千分の 1 スケールで把握できる と考えられる。2万 5 千分の 1 スケールで認 識できる横浜市域の 1 次谷戸数は 3751 か所 である(表 1 )。

谷户数を横浜市域面 積で除した谷戸密度は, $1 \mathrm{~km}$ 当たり 8.7 である。

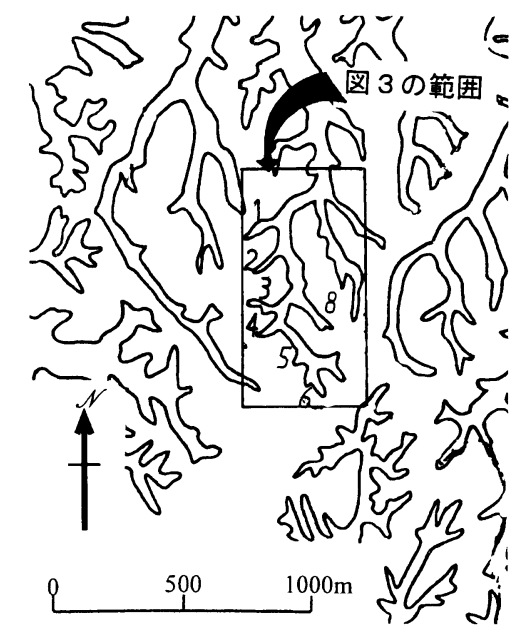

図一 2 横浜市谷戸図拡大図 1:25000スケール横浜市谷戸図の原図の一部図 の数字は 1 次谷戸の数を数えるための番号 


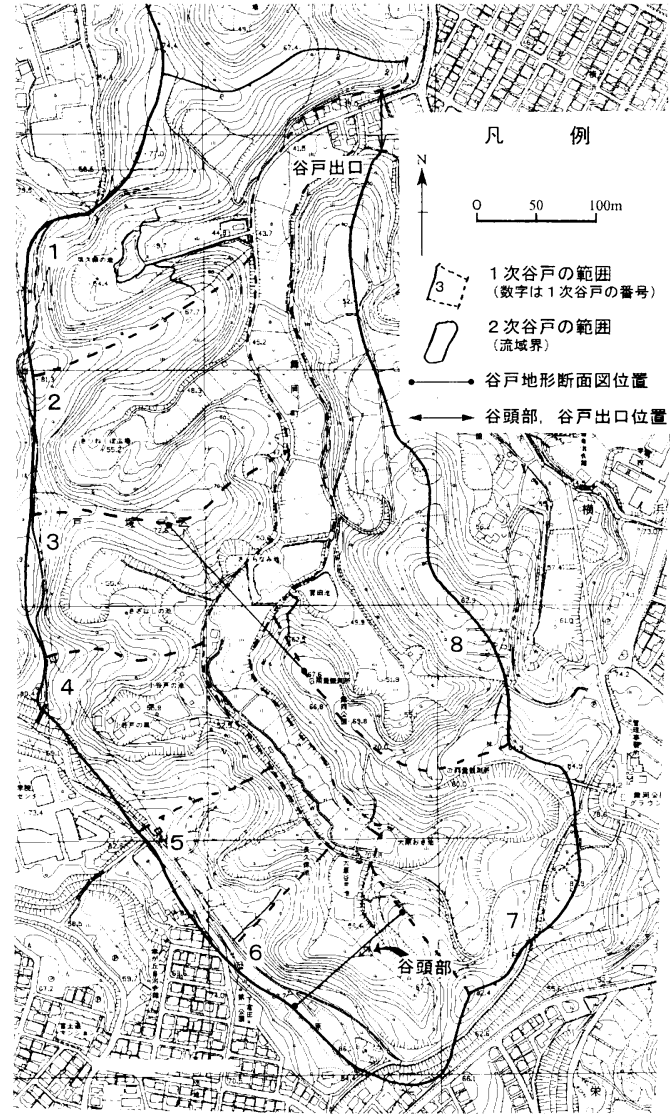

図一 $3 \quad 1: 2500$ スケール地形図

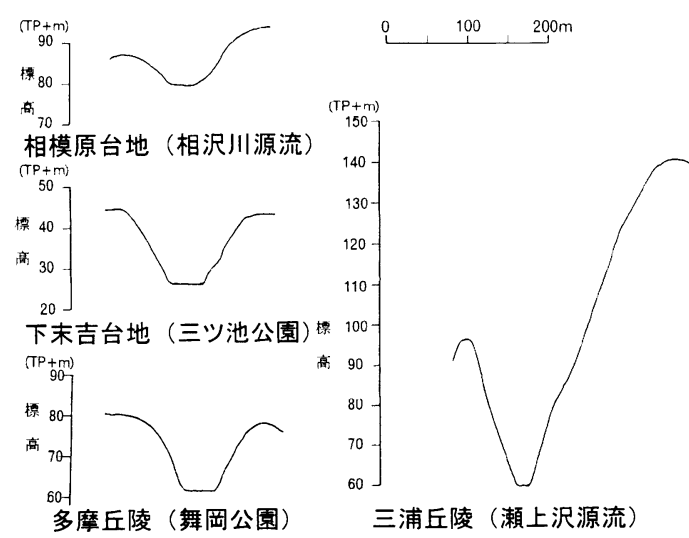

図-4 地形区分ごとの谷頭部の谷戸の断面

(ii ) 谷戸地形の特徵

流域別の谷戸密度および図 1 からも判別できるように，境川本 川付近の谷戸は未発達である。これは相模原台地の形成時期が比 較的に新しく開析が十分に進んでいないためと考えられる。

次に, 谷戸の頂部之平坦面の比高, 平坦面の幅を 2 千 5 百分の 1 地形図（横浜市都市計画局）から見る之（表 2, 図 4 ），三浦 丘陵の谷戸は，比高が他地域に比べ大きく幅も狭く深い谷形状を 示している。谷壁斜面勾配は急で，頂部も山地的である。谷壁斜 面勾配が緩やかで頂部の形状む丸みを帯びている多摩丘陵とは対 称的である。この要因は地形の隆起量が大きいためと考えられる。 なお多摩丘陵・下末吉台地は，形状に差は認められない。

結論として，横浜市域における谷戸地形は，多摩丘陵・下末吉 台地型，三浦丘陵型，相模原台地型の 3 類型に分けられる。

\section{表 -1 横浜市谷戸総括表}

\begin{tabular}{|c|c|c|c|c|c|c|c|c|c|c|c|}
\hline & $\begin{array}{l}\text { 境川 } \\
\text { 本川 }\end{array}$ & 柏尾川 & 侍従川 & 宮川 & 大岡川 & 帷子川 & 滰野川 & 入江川 & 隹罵見川 & その他 & 総 計 \\
\hline 数 & $\begin{array}{c}120 \\
100 \% \\
\end{array}$ & $\begin{array}{c}803 \\
100 \% \\
\end{array}$ & $\begin{array}{c}105 \\
100 \% \\
\end{array}$ & $\begin{array}{c}109 \\
100 \% \\
\end{array}$ & $\begin{array}{c}461 \\
100 \% \\
\end{array}$ & $\begin{array}{c}458 \\
100 \% \\
\end{array}$ & $\begin{array}{c}70 \\
100 \% \\
\end{array}$ & $\begin{array}{c}102 \\
100 \% \\
\end{array}$ & $\begin{array}{l}1,332 \\
100 \% \\
\end{array}$ & $\begin{array}{c}191 \\
100 \% \\
\end{array}$ & $\begin{array}{l}3.751 \\
100 \% \\
\end{array}$ \\
\hline $\begin{array}{c}\text { 地形の消失した谷戸 } \\
\text { (C) }\end{array}$ & \begin{tabular}{|c|}
13 \\
$10.8 \%$ \\
\end{tabular} & $\begin{array}{r}255 \\
31.8 \% \\
\end{array}$ & \begin{tabular}{|c|}
25 \\
$23.8 \%$ \\
\end{tabular} & $\begin{array}{r}39 \\
35.8 \% \\
\end{array}$ & $\begin{array}{r}157 \\
34.1 \% \\
\end{array}$ & $\begin{array}{c}66 \\
14.4 \% \\
\end{array}$ & $\begin{array}{c}6 \\
8.6 \% \\
\end{array}$ & $\begin{array}{r}6 \\
5.9 \% \\
\end{array}$ & $\begin{array}{c}645 \\
48.4 \% \\
\end{array}$ & $\begin{array}{c}22 \\
11.5 \% \\
\end{array}$ & $\begin{array}{l}1,234 \\
32.9 \%\end{array}$ \\
\hline 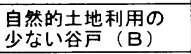 & \begin{tabular}{|c|}
53 \\
$44.2 \%$ \\
\end{tabular} & $\begin{array}{l}271 \\
33.7 \% \\
\end{array}$ & \begin{tabular}{|c|}
29 \\
$27.6 \%$ \\
\end{tabular} & $\begin{array}{r}31 \\
28.4 \% \\
\end{array}$ & \begin{tabular}{|c|}
258 \\
$56.0 \%$ \\
\end{tabular} & $\begin{array}{r}2399 \\
52.2 \% \\
\end{array}$ & $\begin{array}{c}39 \\
55.7 \% \\
\end{array}$ & $\begin{array}{c}74 \\
72.5 \% \\
\end{array}$ & $\begin{array}{r}414 \\
31.1 \% \\
\end{array}$ & \begin{tabular}{|c|}
115 \\
$60.2 \%$ \\
\end{tabular} & $\begin{array}{r}, 523 \\
40.6 \% \\
\end{array}$ \\
\hline 臰然的土地利用の & $\begin{array}{c}54 \\
45.0 \% \\
\end{array}$ & $\begin{array}{c}277 \\
34.5 \% \\
\end{array}$ & $\begin{array}{c}51 \\
48.6 \% \\
\end{array}$ & $\begin{array}{c}39 \\
35.8 \%\end{array}$ & \begin{tabular}{|c|}
42 \\
$9.1 \%$
\end{tabular} & $\begin{aligned} 153 \\
33.4 \%\end{aligned}$ & \begin{tabular}{|c|}
25 \\
$35.7 \%$
\end{tabular} & $\begin{array}{c}22 \\
21.6 \%\end{array}$ & $\begin{array}{c}273 \\
20.5 \% \\
\end{array}$ & $\begin{array}{c}58 \\
30.4 \% \\
\end{array}$ & $\begin{array}{r}944 \\
26.5 \%\end{array}$ \\
\hline 流域面積 $\left(\mathrm{km}^{2}\right)$ & $43.0^{1)}$ & $62.5^{13}$ & $5.2^{11}$ & $8.0^{33}$ & $27.3^{12}$ & $57.9^{92}$ & $9.9^{13}$ & $6.4^{21}$ & 142.7 & & 433 \\
\hline $\begin{array}{c}\text { 谷戸密度 } \\
\left.\text { (か所 / } / \mathrm{km}^{2}\right)\end{array}$ & 2.8 & 12.8 & 20.1 & 13.7 & 16.9 & 7.9 & 7.0 & 15.9 & 9.3 & & 8.7 \\
\hline
\end{tabular}

上段は一次谷戸数、下段は総数に対する割合

流或面樌は.は、横浜「水と緑のまちつくり」(1986,横浜市都市計画局) 基本構想から, “横浜の川 (1995, 横浜市下水道局)より引用した。たたし流域面樌は資料によって異なっており，流域面積の合計は必ずしも

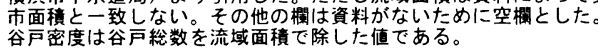

\section{表一 2 横浜市地形別谷戸比較表}

\begin{tabular}{|c|c|c|c|c|c|c|c|c|}
\hline \multirow[b]{2}{*}{ 地形区分 } & \multirow{2}{*}{$\begin{array}{c}\text { 地形面区 } \\
\text { 分 }\end{array}$} & \multirow{2}{*}{ 場 所 } & \multicolumn{2}{|c|}{ 標高 (m) } & \multirow{3}{*}{$\begin{array}{c}\text { 比高 }(\mathrm{m}) \\
\text { 頂部 } \\
\text { 谷頭部 } \\
40 \\
40\end{array}$} & \multirow{2}{*}{$\begin{array}{l}\text { 谷戸 } \\
\text { 次数 }\end{array}$} & \multicolumn{2}{|c|}{ 平坦面の幅(m) } \\
\hline & & & 頂部 & 谷頭部" & & & 谷頭部” & 谷戸出口 \\
\hline \multirow{11}{*}{ 多摩丘陵 } & \multirow{3}{*}{$\begin{array}{l}\text { 地形面が } \\
\text { ない地域 }\end{array}$} & 岩川源流 & 95 & 55 & & 2 & 20 & 45 \\
\hline & & 寺家 & 60 & 35 & 25 & 3 & 20 & 40 \\
\hline & & こども自然 & 84 & 61 & 23 & 2 & 25 & 50 \\
\hline & \multirow{3}{*}{ 多摩 I 面 } & 舞岡 & 86 & 56 & 30 & 2 & 25 & 50 \\
\hline & & 上川井 & 80 & 60 & 20 & 2 & 20 & 40 \\
\hline & & 四季の森 & 80 & 40 & 40 & 3 & 20 & 45 \\
\hline & \multirow{2}{*}{ 多摩 II 面 } & 萑田 & 52 & 30 & 22 & 2 & 25 & 40 \\
\hline & & 早㴊源流 & 80 & 50 & 30 & 2 & 20 & 40 \\
\hline & 早田面 & 北八朔町 & 60 & 35 & 25 & 2 & 30 & 50 \\
\hline & \multirow{2}{*}{ 下末吉面 } & リサーチパーク & 60 & 25 & 35 & 2 & 40 & 60 \\
\hline & & 新橋 & 65 & 40 & 25 & 2 & 25 & 60 \\
\hline \multirow{2}{*}{ 下末吉台地 } & \multirow{2}{*}{ 下末吉面 } & 獅子ヶ谷 & 45 & 15 & 30 & 3 & 50 & 70 \\
\hline & & 三ツ池 & 40 & 15 & 20 & 4 & 40 & 50 \\
\hline \multirow{2}{*}{ 三浦丘陵 } & \multirow{2}{*}{$\begin{array}{l}\text { 地形面が } \\
\text { ない地域 }\end{array}$} & 水取沢 & 130 & 60 & 70 & 1 & 20 & 25 \\
\hline & & 瀬上 & 110 & 50 & 60 & 2 & 15 & 30 \\
\hline 相模原台地 & 武蔵野面 & 相沢川 & 80 & 55 & 25 & 1 & 30 & 40 \\
\hline
\end{tabular}

ところで長年にわたり調査されている谷戸のトンボ相調查結果 をみると, 出現種（偶然の飛来種は除く）では三浦丘陵の円海山 地区 37 種, 多摩丘陵の寺家地区 25 種, 同じく多摩丘陵の新治地 区 25 種となっている。いずれも横浜を代表する谷戸である。な お円海山，寺家には溜池があるが，新治地区にはない。出現種数 の相違のほか, 円海山では普通にいるエゾトンボ科が寺家・新治 にはまったくいないこと，寺家・新治には普通にみられるマユ夕 テアカネ，ヒメアカネが円海山では希になるなど大きな違いがみ られる。寺家上新治の間には溜池に依存する種を除けば大きな差

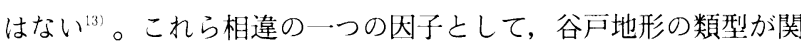
係していることも考えられる。トンボに限らず従来の生物相調査 は, メッシュや土地利用等で整理されていたが, 今後は谷戸類型 による考察も必要になると考えられる。

(3) 谷戸の現況

横浜市域の 1 万分の 1 地形図（国土地理院，平成 $6 \cdot 7$ 年）を 基礎に 2 万 5 千分 1 スケールの谷戸現況図（図 5 ）を作成した。 デー夕は表 1 にまとめた。

図 1 の谷戸図と図 5 の谷戸現況図を比較して 1 次谷戸の地形そ のものが 1234 加, 約 $1 / 3$ 消失している。とくに大規模土地改 変が行われた鶴見川流域では $50 \%$ 近く 1 次谷戸が消失している。

しかしまだ，かなりの谷戸（2467 か所）が残されている。と はいえ谷戸の地形は残されているものの斜面, 谷底面が宅地化さ れるなどして，樹林地・農地・水辺地などの自然的土地利用の少 ない谷戸もある。先の 1 万分の 1 地形図から谷户の流域界の土地 


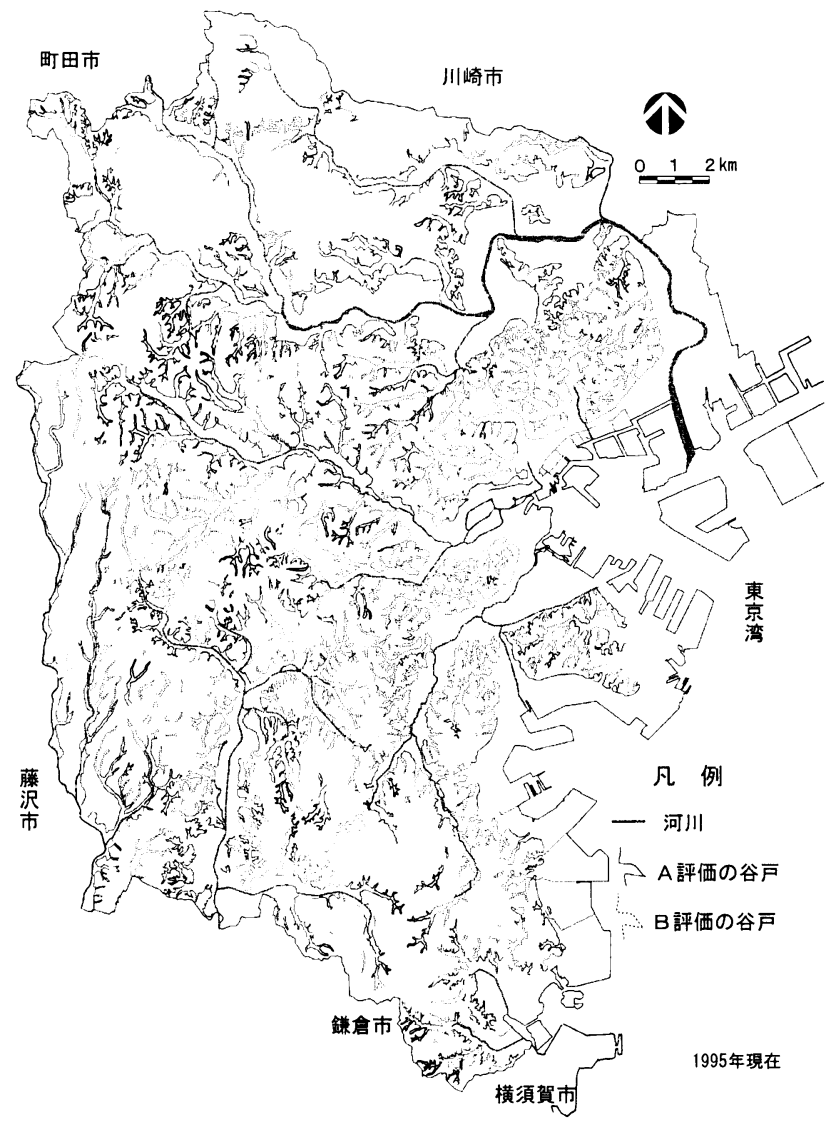

図- 5 横浜市谷戸現況図

利用を調べおおむね $50 \%$ 目安に自然的土地利用の多い谷户 をAランク (944 か所)，少ない谷戸をBランク（1523 か所）に
区分けした。図 5 ではA $\mathrm{A}$ 実線, B は点線で示している。流域別 にみると, 自然的土地利用の多い谷戸（A）は数的には柏尾川 (277 か所), 鶴見川（273 か所）である。

\section{4.まとめ}

第 1 に, 横浜市域の谷戸地形の基底は最終水期の海退期, 埋没 谷としての谷戸地形の原形は縄文海進期以降，そして谷戸生態系 は中世から近世以降に形成，発展したものと推定される。

第 2 に, 谷戸は横浜市域の全域で展開しており，2 万 5 千分の 1 スケールでも確認できる元の 1 次谷戸数は 3751 か所に及ぶ。 現在は 2467 か所が残されている。後者のうち自然的土地利用の 多い谷戸は944 か所である。

第 3 に, その地形的形状は多摩丘陵・下末吉台地型, 三浦丘陵 型，相模原台地型の 3 類型に分けられる。

最後に, 今日の谷户環境の象徴となっているゲンジボタル，ア カトンボ類, トゥキョウダルマガエル等について触れておくと, それら生物は水田もしくはそれに近い湿地環境を生息地としてお り，かつて（3，40 年前まで）は谷戸の外にも普通に生息してい た。谷戸保全市民活動の一部にそれら生物を谷戸固有種であるか のように主張する傾向も見受けられるが, 谷戸生態系の固有種で はない。むしろアシが密植し水路もなかった谷戸生態系の成立前 には，それらは谷戸の中には生息していなかったと推測される。 おそらくは谷戸開発後の移入種であり, 谷戸外の環境悪化のため に谷戸内に閉じこめられた生物である。この認識はエコロジカル・ ネットワーク計画等においても重要な意味を持っている。谷戸固 有種ということになると谷戸外に生息地を拡大することは困難に なるが, 移入種ということになれば, 例えばゲンジボタルなどの 支川や本川での復活の可能性も高くなる。谷戸を生態的拠点之す る流域のエコロジカル・ネットワークもより質の高いものになろ う。

なお本研究を進めるにあたり大澤浩一氏，山道省三氏にご協力 いただきました。ここに感謝の意を表します。

\section{補注・文献}

1）横浜市（1998）：環境エコアップマス タープラン, $52 \mathrm{pp}$

2 ) 岡重文 (1991): 関東地方南西部にお ける中・上部更新統の地質 : 地質調查 月報 4 (11)，553-653，松井健・武内 和彦・田村俊和編（1990）：丘陵地の 自然環境：古今書院, 202pp ほか

3）２）の文献及び貝塚爽平編（1993）: 東京湾の地形・地質之水: 築地書館, $211 \mathrm{pp}$ ，横浜市公害研究所（1984）: 舞岡川源流域の水文調査, $105 \mathrm{pp}$

4 ）山田修三（1990）: 関東地名物語：草 風館， $161 \mathrm{pp}$ その他，柳田国男（19 68）: 地名の研究 : 角川書占, $316 \mathrm{pp}$, 谷川健一（1997）：日本の地名：岩波 書店，226pp 等を参考とした。

5 ）角川日本地名大辞典・神奈川県 (1984): 角川書店, 1363-1367

6 ) 山田前掲書

7 ）鈴木良明編（1994）: 寺家の歷史：横 浜市緑区寺家町 $305,146 \mathrm{pp}$

8 ) 高島緑雄（1997）: 関東中世水田の研 究:日本経済評論社, $188 \mathrm{pp}$

9 ) 山崎不二夫 (1996)：水田ものがたり： 農文協, $188 \mathrm{pp}$ 田淵俊雄（1999）：世界の水田 日本の 水田: 農文協, $220 \mathrm{pp}$

10）港北区郷土史編さん刊行委員会（1986）: 港北区史, $1026 \mathrm{pp}$

11）田口正男 (1997)：トンボの里：信山 社, $144 \mathrm{pp}$
横浜市公害研究所（1986）：ホタルの 生息環境づくり, $121 \mathrm{pp}$

大澤啓志・勝野武彦（2000）：多摩丘 陵南部におけるシュレーゲルアオガエ ル生息の環境条件の把握と保全に関す る考察：ランドスケープ研究 63(5), 495-500

12）横浜市公害研究所 (1988): 横浜市軟弱 地盤層調查報告書, 図面

13）円海山域自然調查会（2000）: 円海山 域の昆虫: 神奈川昆虫談話会, 40-48 横浜ふるさと村自然と文化の会 (1987)： 寺家の自然 : 四季の家, 156 緑区・自然を守る会（1991）：カタク リの咲く谷戸に：文一総合出版，7475

Summary: "Yato" is a landscape unit that is formed by the first order stream, or at least by very upstream part of a river. "Yato" landscape is a mosaic of fountain, stream, agriculture field, woods on lope, and upper land. Ecologically rich "Yato" is one of the most important element in the concept of Ecocity. This article analyses the distribution and ecosystems of "Yatos" in Yokohama City as a fundamental information or the future of Ecocity Yokohama. "Yato" landscape was created during the Jomon transgression. After the medieval ages, valley bottoms were developed for agricultural purposes and there developed the semi-natural ecosystems. Old topographical maps reveal that there were 3,751 "Yatos" with the first order stream in the city area, and the "Yatos" were located all over the area. Many hamlets were named after the "Yato". Yokohama was the city of "Yato". Recent urban development has drastically changed the landuse and topography of "Yatos". Today there are 2,467 "Yatos" remain, and only 944 "Yatos" keep natural and semi-natural landuse. 